Original Paper

doi 10.15826/recon.2018.4.4.019

\title{
Strategic priorities in the development of large Russian cities
}

\author{
Ivan A. Antipin \\ Ural State University of Economics, Ekaterinburg, Russia; e-mail: aia87@mail.ru
}

\begin{abstract}
The paper discusses problems of strategic planning and management in the Russian Federation, primarily the lack of comprehensive methodological approaches to strategic planning in regions and cities, especially to selecting priorities of their socio-economic development. The conceptual framework of this research is based on strategic management theory and theories of regional and spatial economics. The paper also reviews Russian and international approaches to the concept of strategy and to strategic planning and management in general. The author analyses the key strategic planning documents of million-plus Russian cities, such as Perm, Novosibirsk, Ekaterinburg, Kazan, and others. These cities are a major driving force behind the country's economic development. In the paper, they are divided into three groups depending on the time period of their strategies. The conclusion is made that the optimal choice of priorities and adequate control over the implementation of these strategies are crucial for their success. In other words, it is necessary to improve the currently existing mechanisms of strategic planning and management to ensure more efficient development of urban territories. Moreover, most strategies focus only on those processes and phenomena that fall within the jurisdiction of local authorities although it would be much more effective to involve all groups of stakeholders and facilitate their cooperation in achieving common goals of the city's development.
\end{abstract}

\section{KEYWORDS}

strategy, strategic planning, strategic management, large city, priorities of urban development

\section{FOR CITATION}

Antipin, I. A. (2018) Strategic priorities in the development of large Russian cities.

R-economy, 4(4), 144-150.

doi: $10.15826 /$ recon.2018.4.4.019

\section{Стратегические приоритеты развития крупных российских городов}

\section{И. А. Антипин}

Уральский государственньй экономический университет, Екатеринбург, Russia; e-mail: aia87@mail.ru

\begin{abstract}
АННОТАЦИЯ
Статья посвящена анализу проблем процессов стратегического планирования и управления в Российской Федерации, одной из которых является отсутствие единых методических подходов к формированию документов стратегического планирования территорий, в том числе к определению перечня направлений их стратегического развития. Методологическая база исследования основывается на теоретических положениях стратегического менеджмента, региональной и пространственной экономики. Подходы российских и зарубежный ученых к стратегиям, этапы эволюции стратегического планирования в России, а также особенности разработки (актуализации) документов стратегического планирования территорий раскрыты путем использования совокупности методов: диалектического, причинно-следственного и т.д. Представлены стратегические цели, целевые ориентиры современного развития Российской Федерации. Акцентировано внимание на необходимости применения механизмов стратегического планирования и стратегического управления развитием территорий. Проанализированы приоритеты, закрепленные в основных документах стратегического планирования мегаполисов Российской Федерации. Сформулированы рекомендации по определению состава приоритетных направлений стратегии социально-экономического развития. Теоретическая и практическая значимость исследования заключается в том, что оптимальное выстраивание приоритетов стратегического развития, их грамотная реализация, организация системы стратегического контроля и т.д. обуславливают прогрессивность социально-экономического развития территорий различных иерархических уровней.
\end{abstract} (C) Ivan A. Antipin, 2018

\section{КЛЮЧЕВЫЕ СЛОВА}

стратегия, стратегическое планирование, стратегическое управление, крупный город, приоритеты городского развития

\section{ДЛЯ ЦИТИРОВАНИЯ}

Antipin, I. A. (2018) Strategic priorities in the development of large Russian cities. R-economy, 4(4), 144-150. doi: $10.15826 /$ recon.2018.4.4.019 


\section{Introduction}

To ensure a breakthrough in Russia's scientific, technological and socio-economic development, to raise the living standards, to create comfortable conditions for life and work, the government of the Russian Federation set the goals of national development for the period until 2024․ These goals include the following: "to accelerate technological development of the Russian Federation and increase the number of organizations engaged in technological innovation; to ensure digitalization in economy and in the social sphere; to put every effort into making Russia one of the top five world economies by enhancing economic growth so that growth rates would exceed the world rates and by maintaining macro-economic stability; to create a highly productive export-oriented sector relying on modern technologies and highly qualified workforce within the key branches of economy, primarily manufacturing industry and agriculture"2.

This paper aims to analyse strategic planning documents of large Russian cities and to provide

${ }^{1}$ On National and Strategic Goals of Development of the Russian Federation Until 2024: Decree of the President of the Russian Federation of May 7, 2018 No. 204. Retrieved from http://www.garant.ru/products/ipo/prime/doc/71837200/

${ }^{2}$ Ibid. recommendations for selecting priorities of their socio-economic development and improving their strategic planning and management practices.

\section{Methodology}

Our study of large Russian cities is based on a comprehensive analysis of their development strategies or, in the absence of an approved strategy, other similar documents. Our analysis also focuses on the key stages in the cycle of strategic planning and management. The methodological framework comprises the dialectical method and cause-and-effect method; analysis of the environment - internal and external - methods of strategic analysis; goal-setting - mission, aim, system (tree) of goals, system (tree) of problems and causes; strategy building - priorities, programs, and projects; mechanisms of strategy implementation; system of monitoring and control over strategy implementation.

In this article, we are considering only the cases of million-plus Russian cities and their strategies.

Strategic planning and management has been extensively discussed in contemporary literature. There are different definitions of the term strategy (starting from the micro-level) (see Table 1).

Table 1

\section{Definitions of the term "strategy"}

\begin{tabular}{|c|c|}
\hline Source & Definition \\
\hline G. B. Kleiner & $\begin{array}{l}\text { trategy of an enterprise is a complex of coordinated decisions that have a major impact on the oper- } \\
\text { tion of this enterprise and that will have an all but irreversible long-term effect on its performance [1]. }\end{array}$ \\
\hline M. Porter & $\begin{array}{l}\text { trategy is a set of offensive or defensive actions to create a defensible position in an industry, to cope } \\
\text { accessfully with competitive forces and thus get a higher return on investment [2]. }\end{array}$ \\
\hline $\begin{array}{l}\text { A. A. Thompson, } \\
\text { A. J. Strickland III }\end{array}$ & $\begin{array}{l}\text { Strategy is a set of competitive changes and business approaches that managers perform to achieve the } \\
\text { best performance of the company. It is the managerial plan to enhance the organization's position in } \\
\text { the market, boost customer satisfaction and achieve performance targets [3]. }\end{array}$ \\
\hline I. Ansoff & Strategy is a set of rules for decision making to guide the behaviour of an organization [4]. \\
\hline $\begin{array}{l}\text { H. Mintzberg, } \\
\text { J. B. Quinn, } \\
\text { S. Ghoshal }\end{array}$ & $\begin{array}{l}\text { Strategy is a combination of five Ps: } \\
\text { 1. strategy as a plan; } \\
\text { 2. strategy as a ploy - a manoeuvre intended tooutwit an opponent or competitor; } \\
\text { 3. strategy as a pattern, consistency in behaviour, whether or not intended; } \\
\text { 4. strategy as a position, that is, a means of locating an organization in what organization theorists like } \\
\text { to call an "environment"; } \\
\text { 5. strategy as a perspective, its content consisting not just of a chosen position, but also of an ingrained } \\
\text { way of perceiving the world [5]. }\end{array}$ \\
\hline $\begin{array}{l}\text { E. G. Animitsa, } \\
\text { V. S. Bochko }\end{array}$ & $\begin{array}{l}\text { Strategy is a prognostic plan incorporating mutually conditioned goals and objectives of the city's de- } \\
\text { velopment, internal resources, policies and major organizational activities (or programs and projects) } \\
\text { aimed at achieving the goals and implemented within the approved city policy [6]. }\end{array}$ \\
\hline I. D. Turgel & $\begin{array}{l}\text { Strategy is an institutionalized process of combining the existing and potential resources to achieve } \\
\text { the key goals of urban development. This process relies on comprehensive analysis of the internal and } \\
\text { external environment and should be approved by the local community [7]. }\end{array}$ \\
\hline E. A. Utkin & $\begin{array}{l}\text { Strategy is a detailed comprehensive plan intended to enable the organization to fulfill its mission and } \\
\text { achieve its goals [8]. }\end{array}$ \\
\hline R. A. Fatkhutdinov & Strategy is a program or a general plan of management to achieve strategic goals in any sphere [9]. \\
\hline N. M. Surnina & $\begin{array}{l}\text { Strategy is a direction, a trajectory of future development which is expected to lead to the achievement } \\
\text { of desired goals [10]. }\end{array}$ \\
\hline
\end{tabular}


In line with the best practices of strategic planning, both Russian and international, we understand a strategic plan (strategy) as a statement of general consensus about the priorities (strategically important areas) in the development of the territory shared by various groups and communities [11]. Therefore, it is particularly important to take into consideration interests of a wide range of stakeholders while selecting strategic priorities [12].

\section{Strategic Planning and Strategic Management in the Russian Federation}

Systemic transformations in the country's strategic development require coordinated effort of all its constituent units. The Federal Law No. 172-Ф3 “On Strategic Planning in the Russian Federation"3 was approved in June 2014.

Strategic planning in Russia suffers from the lack of appropriate legislation to regulate this process. In 1997, the first strategic document was designed - "Strategic Plan of St. Petersburg", which was followed by similar documents of other large Russian cities [13]. There exists a vast body of research concerning development of large and super-sized cities [14-16].

We believe that strategic planning and management in Russia is currently facing the following problems: the lack of comprehensive methodological guidance, which is crucial for designing and implementing strategic plans; the lack of adequate legislation; insufficient coordination of strategic and territorial planning and management; the lack of a clear understanding as to who should be involved in these processes as well as the inadequate organizational structure; and the lack of integral mechanisms for strategic planning control and implementation.

Therefore, it is essential to continue improving the quality of strategic planning and management, especially in cities and regions (processes of designing, updating and implementing these strategies). It should be noted that forecasting [17], strategic planning and management, including methodological guidance [18-20], are the focus of much scholarly attention in Russia.

\section{Priorities of Strategic Development of Large Russian Cities}

Large cities are among the major drivers of economic development in Russia. In this paper we are

${ }^{3}$ On Strategic Planning in the Russian Federation: Federal Law of June 28, 2014 No. 172-Ф3. Retrieved from http://www. kremlin.ru/acts/bank/38630 going to discuss priorities described in the strategies of million-plus Russian cities (see Table 2$)^{4}$.

Table 2

Key strategic planning documents of Russian million-plus cities

\begin{tabular}{|c|c|}
\hline City & $\begin{array}{l}\text { Current version of the key strategic } \\
\text { planning document }\end{array}$ \\
\hline Volgograd & $\begin{array}{l}\text { Strategy of Socio-Economic Development } \\
\text { of Volgograd until } 2030\end{array}$ \\
\hline Voronezh & $\begin{array}{l}\text { Strategic Plan of Socio-Economic Devel- } \\
\text { opment of the Municipality of Voronezh } \\
\text { until } 2020\end{array}$ \\
\hline Ekaterinburg & $\begin{array}{l}\text { Strategic Plan for Development of Ekater- } \\
\text { inburg until } 2030\end{array}$ \\
\hline Kazan & $\begin{array}{l}\text { Strategy of Socio-Economic Development } \\
\text { of the Municipality of Kazan until } 2030\end{array}$ \\
\hline Krasnoyarsk & $\begin{array}{l}\text { Program of Socio-Economic Develop- } \\
\text { ment of Krasnoyarsk until } 2020\end{array}$ \\
\hline $\begin{array}{l}\text { Nizhny } \\
\text { Novgotod }\end{array}$ & $\begin{array}{l}\text { Strategy of Socio-Economic Development } \\
\text { of Nizhny Novgorod for 2017-2022 }\end{array}$ \\
\hline Novosibirsk & $\begin{array}{l}\text { Strategic Plan for Sustainable Develop- } \\
\text { ment of Novosibirsk }\end{array}$ \\
\hline Omsk & $\begin{array}{l}\text { Strategy of Socio-Economic Development } \\
\text { of Omsk until } 2025\end{array}$ \\
\hline Perm & $\begin{array}{l}\text { Strategy of Socio-Economic Development } \\
\text { of the Municipality of Perm until } 2030\end{array}$ \\
\hline Rostov-on-Don & $\begin{array}{l}\text { Key Areas of the Strategy of Socio-Eco- } \\
\text { nomic Development of Rostov-on-Don } \\
\text { until } 2025\end{array}$ \\
\hline Samara & $\begin{array}{l}\text { Strategy of Comprehensive Development } \\
\text { of the Municipality of Samara until } 2025\end{array}$ \\
\hline Chelyabinsk & $\begin{array}{l}\text { Strategy of Development of Chelyabinsk } \\
\text { until } 2020\end{array}$ \\
\hline
\end{tabular}

The data cover all Russian million-plus cities, except for Ufa, whose strategy has not been approved yet and, therefore, has not been made publicly available.

Strategies of Russian million-plus cities can be divided into three groups: strategies approved for the period until 2020 (Voronezh, Krasnoyarsk, Novosibirsk, and Chelyabinsk); until 2030 (Volgograd, Kazan, Perm, and Ekaterinburg); and until 2025 or another period (Omsk, Rostov-on-Don and Samara (until 2025) and Nizhny Novgorod (2017-2022)).

First group. The priorities of socio-economic development in Voronezh are defined as follows: "development of the human potential and creation of supportive and healthy urban environment; formation of efficient urban agglomeration; innovative development of the city's economy and its integration into the Russian and international economy"

\footnotetext{
${ }^{4}$ In this paper, the terms strategic planning document, strategic plan and strategy are used interchangeably.

5 On the Approval of the Strategic Plan of Socio-Economic Development of the Municipality of Voronezh until 2020: Decree of Voronezh City Duma of July 14, 2010 No. 147-III (version of December 20, 2017 No. 740-IV). Retrieved from http://www. voronezh-city.ru/administration/structure/detail/10763
} 
For each priority area the document defines the matters which fall within the responsibility of local authorities. For the third priority area their responsibilities were described the following way: "enhance formation and development of new knowledge-intensive industries and boost their competitiveness on Russian and world markets; stimulate manufacturing output and ensure growth in the share of innovative products; maximize growth in the number of small innovative businesses and their share in the economy of the city and the region; participate in the processes of clusterization of the city's socio-economic space; create a favourable investment climate; catalyze integration of the city into the socio-economic space of the country and the world educational, scientific and informational space; enhance modernization of the existing large industrial enterprises, their competitiveness and efficiency; ensure energy efficiency and energy saving in all spheres of the city's economy; and assist in establishing zones of innovative development within the city area (and suburban areas of the region's municipalities)"'.

Local authorities are also expected to contribute to the creation and development of special zones, technoparks and clusters, which are seen as crucial for innovative socio-economic development. As the Strategy points out, "...participation of local authorities in clusterization of the city's socio-economic space will contribute to its economic and social growth and provide more opportunities for integration of manufacturing, educational, and research organizations into the national and global space"7.

In its strategic documents, Krasnoyarsk ${ }^{8}$ is described as a site with a multi-sectoral manufacturing industry and abundant production facilities, which makes it suitable for promoting and enhancing technical innovation. The strategic priorities of its development correspond to those of Krasnoyarsk region, Siberia and Russia in general.

The Strategic Plan of Novosibirsk states that "it is possible to achieve a stable improvement in the standards of living of all groups of city resi-

\footnotetext{
${ }^{6}$ On the Approval of the Strategic Plan of Socio-Economic Development of the Municipality of Voronezh until 2020: Decree of Voronezh City Duma of July 14, 2010 No. 147-III (version of December 20, 2017 No. 740-IV). Retrieved from http://www. voronezh-city.ru/administration/structure/detail/10763

Ibid.

${ }^{8}$ On the Approval of the Program of Socio-Economic Development of Krasnoyarsk until 2020: Decree of Krasnoyarsk City Council of Deputies of October 13, 2011 No. B-267. Retrieved from http://www.admkrsk.ru/citytoday/economics/social situation/Pages/developmentprogram.aspx
}

dents by raising economic prosperity, enhancing the educational, cultural and spiritual potential, ensuring public safety and raising the quality of the urban environment" .

According to the innovative scenario underlying the Strategy of Chelyabinsk, the city is going to acquire a new status of modern metropolis with the corresponding look, infrastructure, level of services and standards of living. The Strategy sets a three-level task for ensuring the city's technological development: "transition from the import of technologies to adoption of technologies and independent creation of new technologies" 10 .

For sustainable development of Chelyabinsk as an industrial, scientific, cultural and sport centre with high standards of living, it is essential to focus on qualitative changes in each of the key spheres. By enhancing its economic performance, Chelyabinsk is expected to secure itself a favourable position in the global division of labour, which would contribute to its development in the nearest decades.

Second group. The Strategy of Volgograd includes four priorities: "development of the human capital: city residents need high-quality services in health care, education, culture, and intellectual development as the quality of these services will determine who will be living and working in Volgograd in the future; development of innovation-driven economy: to enhance the potential of the city's economy it is vital to create favourable conditions for business (management, infrastructure, investment and entrepreneurial climate); improvement of the urban environment (public amenities, utilities and transport, affordable housing, making the city more disabled-accessible), which will determine residents' overall satisfaction with their city as a place suitable for life and work; and, finally, development of local self-government as a key to high quality city management by making it more efficient and open for interactions with people and business, building a civil society and creating a single information space" 11 .

9 On the Approval of the Strategic Plan for Sustainable Development of Novosibirsk: Decree of the City Council of March 28, 2005 No. 575. Retrieved from http://novo-sibirsk.ru/to-citizens/economy/strategy/

${ }^{10}$ On the Approval of the Strategy of Development of Chelyabinsk until 2020: Decree of Chelyabinsk City Duma of November 26, 2009 No. 8/1. Retrieved from http://chelduma.ru/ reshenie-chelyabinskoy-gorodskoy-dumy-chetvertogo-sozyva-ot-26112009-g-no-81-o-strategii-razvitiya

${ }^{11}$ On the Approval of the Strategy of Socio-Economic Development of Volgograd until 2030: Decree of Volgograd City Duma of January 25, 2017 No. 53/1539. Retrieved from http:// www.volgadmin.ru/d/strategy2030/index 
In $\mathrm{Kazan}^{12}$, the choice of priorities relies on several groups of criteria, including advanced world practices and modern theories and concepts such as the green city, resilient city, global city, and a smart city. The Strategy of Kazan focuses on three interconnected priority areas: "formation and accumulation of the human capital; creation of comfortable space to develop the human capital; and creation of economic relations and social institutions that would ensure demand for the human capital in the city's economy and enhance the performance of the human capital"13.

In Perm, the strategic goals and objectives are grouped according to the following functional areas: "social sphere; public security; economic development; development of infrastructure; spatial development; and development of the municipal administration system" ${ }^{14}$. It is planned to ensure economic development by "diversifying the economy, which is based on dynamic innovative sectors, and by creating conditions for knowledge-driven economy and transition to the sixth technological mode" 15 .

One of the key strategic areas for the development of Ekaterinburg is turning the city into "an interregional innovation-oriented industrial and financial centre". This priority area thus focuses on "creating the largest interregional centre of 'new economy', capable of participating in global economic processes by enhancing the competitiveness of the city's financial and industrial complex and by creating favourable conditions for sustainable development of innovation-driven business and investment"16.

This priority area includes the following strategic goals: "to establish a production centre to maximize the efficiency and innovation potential of the city's industrial complex and to create conditions for accelerated development of new technological niches and production service; to create an interregional centre for attracting financial and investment resources and thus improve business,

${ }^{12}$ On the Approval of the Strategy of Socio-Economic Development of the Municipality of Kazan until 2030: Decree of Kazan City Duma of December 14, 2016 No. 2-12. Retrieved from https://www.kzn.ru/o-kazani/strategiya-kazani-2030/

${ }^{13}$ Ibid.

${ }^{14}$ On the Approval of the Strategy of Socio-Economic Development of the Municipality of Perm until 2030: Decree of Perm City Duma of April 22, 2014 No. 85. Retrieved from http://www. gorodperm.ru/actions/strategy/conception development/

${ }^{15}$ Ibid.

${ }_{16}$ On Amendment of the Decree of Ekaterinburg City Duma of June 10, 2003 No. 40/6 "On the Strategic Plan of Ekaterinburg: Decree of Ekaterinburg City Duma of May 25, 2018 № 12/81”. Retrieved from http://www.egd.ru/docs/acts/ aview b6848 institutional and infrastructural conditions for innovative economic development, to enhance the efficiency of business investment and to establish the largest regional decision-making centre; to develop sectors of digital economy and facilitate cooperation between administration, business and the public; to provide efficient information and communications services and the corresponding infrastructural, institutional, technological and human resources"17.

Third group. The Strategy of Omsk prioritizes knowledge-intensive industries. The role of the city administration is described the following way: "to create federal and regional centres of knowledge-intensive mechanical engineering through cooperation between the city administration and industrial enterprises; to facilitate cooperation between the participants of the comprehensive program Innovative Transport for Remote Regions of the Far North, Siberia, and the Far East (Innovative Transport of the North) and to assist in the selection of projects within the program; to facilitate cooperation between the participants of the roadmap of the project Expanded Use of High-Technology Products of Knowledge-Intensive Organizations of Omsk Region, Including Import-Substituting Products in the Interests of OAO Gazprom and to assist in the selection of projects; to provide enterprises with organizational and financial support and thus develop renewable energy sources such as solar power engineering and new principles of energy generation; to provide organizational and financial support for the implementation of the project to establish a manufacturing and logistics complex; to provide financial support to small and medium entrepreneurship projects engaged in development of advanced types of production, technologies or services"18.

The main aim outlined in the Strategy of Rostov-on-Don is "to ensure the city's transition to innovation-driven economy, advanced sphere of social services to meet residents" needs in professional and creative self-realization, healthy lifestyle and spiritual development. The Strategy seeks to guide the city's development as one of the leading scientific, educational, cultural, financial,

17 On Amendment of the Decree of Ekaterinburg City Duma of June 10, 2003 No. 40/6 "On the Strategic Plan of Ekaterinburg: Decree of Ekaterinburg City Duma of May 25, 2018 № 12/81". Retrieved from http://www.egd.ru/docs/acts/ aview b6848

${ }_{18}$ On the Approval of the Strategy of Socio-Economic Development of Omsk until 2025: Decree of the Administration of Omsk City of July 9, 2014 No. 938-n. Retrieved from http:// admomsk.ru/web/guest/progress/socioeconomic 
economic, and transportation centres of federal significance, as the capital of sourthern Russia"19. To fulfil this vision, for the period until 2025, it is planned to pursue three strategic goals, one of which is the "formation of innovative and efficient economy, open to the world and attractive for investment" 20 . This goal includes the following strategic priorities: "development of Rostovon-Don as an innovative technological, research and education centre of federal and international significance; Rostov-on-Don as an international economic centre: the city open to the world; Rostov-on-Don as the leading trade centre and transport hub of southern Russia; Rostov-on-Don as an interregional financial and economic centre; development and realization of the potential of local businesses"21.

The Strategy of Samara focuses on the following areas: "innovative and technological development of the manufacturing industry; enhanced development of business environment and entrepreneurship; accelerated development of communications; development of transport and logistics; development of tourism and recreation industry; sustainable urban development; spatial development and formation of creative urban environment; development of local communities; cultural development; and development of education" 22 .

The key area of industrial policy in Samara is "the city's transition to high technologies, which would provide competitive, sustainable and resource-efficient module-based production and transition to development and transfer of commercially successful technologies for the global market" 23.

In the Strategy of Nizhny Novgorod, the goal Economic Development comprises four strategic areas: "development of investment potential; development of the cluster policy; retaining and de-

19 On the Approval of the Key Areas of the Strategy of Socio-Economic Development of Rostov-on-Don until 2025: Decree of Rostov-on-Don City Duma of December 18, 2012 No. 372. Retrieved from http://rostov-gorod.ru/upload/uf/9e5/9e5a8e9cd32821e9aba6d0605e7d96a5.doc

${ }^{20}$ Ibid.

${ }^{21}$ Ibid.

${ }^{22}$ On the Approval of the Strategy of Comprehensive Development of the Municipality of Samara until 2025On the Approval of the Strategic Plan of Socio-Economic Development of the Municipality of Voronezh until 2025: Decree of the Duma of the Municipality of Samara of September 26, 2013 No. 358. Retrieved from http://samgd.ru/upload/mirrors/www.gordumasamara. $\underline{\mathrm{ru} / \text { docs/decisions/1380139200/Strategiya ot 26.09.13.pdf }}$

${ }^{23}$ Ibid. veloping the workforce; and development of entrepreneurship and competitive environment"24.

Our study of strategic priorities and indicators of socio-economic development of large Russian cities has shown the following: firstly, the results achieved within each priority area should contribute to the attainment of more general goals of socio-economic development. It should be noted that the main aim of any such strategy is to raise the standards of life in the city. Thus, the complex of priority areas must ensure the development of the city's human potential and economy. Depending on their significance, these specializations and priorities can be divided into separate groups such as engineering, transport and social infrastructure, environmental sustainability, public amenities and so on. Secondly, strategic planning should take into consideration priorities, projects and programs realized on the federal and regional levels (macro-levels) but also the interests of the areas surrounding the city in question.

\section{Conclusion}

Strategic planning and management are the main tools in organizing cooperation between the authorities and other groups of stakeholders, thus enabling them to work together towards common goals. Our analysis has led us to the following conclusions:

1. In Russia, the key strategic planning documents (strategies, strategic plans and so on) first started to be designed in large cities and underwent certain transformations due to the changes in stakeholders' interests and the objective processes in the country's development (economy, politics, and so on). Some of these documents have been updated while others are still used in their original versions.

2. We have analyzed the priorities in strategic development of Russian million-plus cities described in the corresponding documents. Large cities are the driving force behind Russia's economic development, which means that careful strategic planning and conscientious management are able to ensure high rates of their development.

3 . We found that one of the main mistakes that is made while designing or updating strategies is to focus only on those processes and phenomena that fall within the jurisdiction of local authorities and

${ }^{24}$ On the Approval of the Strategy of Socio-Economic Development of Nizhny Novgorod for 2017-2022 Decree of the City Administration of January 25, 2017 No. 190. Retrieved from http:// нижнийновгород.pф/gorod/biznes/strategicheskoe-planirovanie/dokumenti-strategicheskogo-planirovaniya/strategiya-sotsialno-ekonomicheskogo-razvitiya-goroda-nizhne/ 
have local significance. Such approach generates infeasible strategies. Instead, a strategy should imply consolidated efforts of all groups of stakeholders regardless of their power, competences and so on and should cover all the processes on the city's territory.
Thus, a general revision of the methodical approaches to strategizing is required, which will allow the country's government to create a unified system of strategic planning and management applicable for all levels of territories.

\section{References}

1. Kleiner, G. B. (2010). Systemic Structure and Systemic Regulation of Economy. In G. B. Kleiner (Ed.), System Analysis in Economics: Proceedings of Scientific and Practice Conference, Moscow, Nov. 24-25, 2010 (pp. 90-96). Moscow: TSEMI RAN. (In Russ.)

2. Porter, M. (1999). On Competition. U.S., A Harvard Business Reviev Book, McGraw-Hill.

3. Thompson, Jr. A. A., Strickland III, A. J. (2001). Strategic Management: Concepts and Cases (12 $2^{\text {th }}$ ed.). Boston, Mass.: McGraw-Hill/Irvin.

4. Ansoff, I. (1988). The New Corporate Strategy. New York: Wiley.

5. Mintzberg, H., Lampel, J., Quinn, J. B., \& Ghoshal, S. (2003). The strategy process: concepts, contexts, cases ( $4^{\text {th }}$ ed.). Harlow: Pearson Education.

6. Animitsa, E. G. et al. (2003). Strategy of Development of a Large City: Looking into the Future. Ekaterinburg: Uralsky rabochy. (In Russ.)

7. Turgel, I. D. (2001). Mono-Specialized City: Theory and Practice of Strategic Management of Socio-Economic Development. Ekaterinburg: Publishing House of the Ural Academy of Mining and Geology. (In Russ.)

8. Utkin, E. A., \& Denisov, A. F. (2001) State and Municipal Management. Moscow: Tandem, EKMOS. (In Russ.)

9. Fatkhutdinov, R. A. (2004). Strategic Management. Moscow: Delo. (In Russ.)

10. Surnina, N. M. (2004). Methods of Strategic Analysis and Planning on the National, Regional, and Corporate Levels (Case Studies). Ekaterinburg: Publishing House of the Ural State University of Economics. (In Russ.)

11. Vetrov, G. Yu. (Ed.) (2009). Management of Municipal Economic Development. Moscow: Institute of Urban Economics. (In Russ.)

12. Risin, I. E., \& Shatalova, E. A. (2008). Innovation in the System of Strategic Planning of Socio-Economic Development of Cities: International Experience. Innovatsionnyi vestnik region, (1), 4-7. (In Russ.)

13. Zhikharevich, B. S. (2006). $10^{\text {th }}$ Anniversary of City Strategies in Russia. Rossiiskoe ekspertnoe obozrenie, (2), 15. (In Russ.)

14. Antipin, I. A. (2010). Megapolis: Formation and Development in an Old Industrial Region. Upravlenets = The Manager, (5-6), pp. 24-31. (In Russ.)

15. Zubarevich, N. V. (2002). Large Russian Cities as "Agents" of Globalization. Rossiya i sovremennyj mir, (4), 97-101. (In Russ.)

16. Quigley, J. M. (1998). Urban Diversity and Economic Growth. Journal of Economic Perspectives, 12(2), 127-138.

17. Lavrikova, Y. G., Antipin, I. A., Pryadein, A. A., \& Suvorova, A. V. (2016). Major City Development Forecast: Designing the Innovative Future. Economic and Social Changes: Facts, Trends, Forecast, (6), 214-235. (In Russ.) doi: 10.15838/esc.2016.6.48.12

18. Animitsa, E. G., Bochko, V. S., Peshina, E. V., \& Animitsa, P. E. (2010). Conceptual Approaches to Designing a Development Strategy for a Mono-city. Ekaterinburg: Ural Federal University. (In Russ.)

19. Surnina, N. M., \& Shishkina, E. A. (2013). Developing the Methodology for Regional Strategic Planning: Increasing Coherence and Effectiveness. Upravlenets = The Manager, (1), 56-63. (In Russ.)

20. Antipin, I. A. (2011). Improvement of the Local Land Market's Largest City: A Strategic and Spatial Planning (Methodological Foundations). Municipality: Economics and Management, (1), 50-61. (In Russ.)

\section{Information about the author}

Ivan A. Antipin - PhD in Economics, Associate Professor, Department of Regional and Municipal Economy and Management, Ural State University of Economics (62/45, 8 Marta/Narodnoy voli str., Ekaterinburg, Russia); e-mail: aia87@mail.ru. 